\title{
The Readiness of Lecturers in Online Learning During the Covid-19 Pandemic at the Faculty of Information Technology and the Faculty of Economics and Business
}

\author{
M. J. Dewiyani Sunarto \\ Department of Information System, Faculty Technology and Informatics \\ Universitas Dinamika, Surabaya, Indonesia
}

\begin{tabular}{|c|c|}
\hline 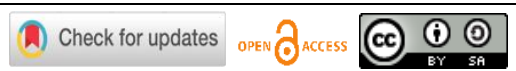 & DOI : https://doi.org/10.46245/ijorer.v2i1.70 \\
\hline Sections Info & ABSTRACT \\
\hline Article history: & \multirow{11}{*}{$\begin{array}{l}\text { This research aims to determine the readiness of lecturers in implementing } \\
\text { online learning on both faculties at a University in Surabaya during the } \\
\text { first semester of the pandemic, especially in terms of (1) the use of } \\
\text { synchronous learning mode, (2) the use asynchronous learning mode with } \\
\text { e-learning, (3) the strengths and weaknesses of online learning that have } \\
\text { been implemented by lecturers. This research was conducted on } 126 \\
\text { lecturers in both faculties with a total of } 350 \text { classes. The research } \\
\text { instrument used an electronic log from the campus e-learning application, } \\
\text { and was analyzed using a descriptive method. The results showed that (1) } \\
\text { the use of synchronous learning mode was used by } 72 \% \text { and } 64 \% \text { of the } \\
\text { total amount of learning performed at the Faculty of Information } \\
\text { Technology and at the Faculty of Business Economics, respectively (2) the } \\
\text { use of campus e-learning as the media for asynchronous learning for } \\
\text { delivering materials by } 94 \% \text { and } 50.01 \% \text { (3). The strength of online learning } \\
\text { for lecturers is the availability of supporting applications and teaching } \\
\text { materials which can be used by learners, while the weakness is on the } \\
\text { understanding of online philosophy. From the results of this research, it is } \\
\text { recommended to increase the readiness of lecturers to perform online } \\
\text { learning, in the form of understanding the online philosophy, and } \\
\text { institutional support to provide interesting contents for online learning, so } \\
\text { it can be carried out in accordance with its philosophy, as asset for future } \\
\text { online learning, even though if there will be no Covid-19 Pandemic. }\end{array}$} \\
\hline Submitted: December 07, 2020 & \\
\hline Final Revised: January 09, 2021 & \\
\hline & \\
\hline Published Online: January 31, 2021 & \\
\hline Keywords: & \\
\hline Asynchronous Learning & \\
\hline & \\
\hline Readiness of Lecturers & \\
\hline Synchronous Learning & \\
\hline 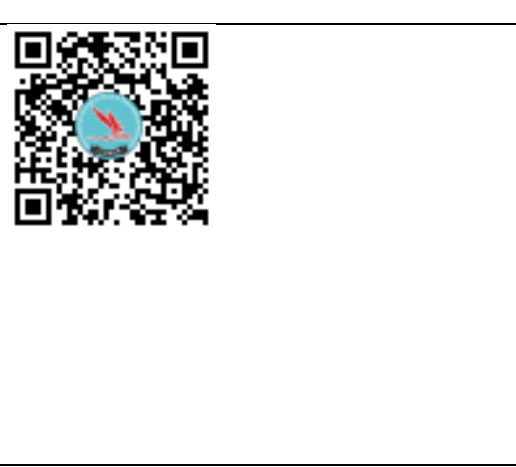 & \\
\hline
\end{tabular}

\section{INTRODUCTION}

The Covid-19 pandemic period in Indonesia, which began in March 2020, has changed the entire order of life, including the world of education. The Indonesian Ministry of Education and Culture immediately reacted quickly to these changes, by issuing an online learning policy since March 2020 at all levels of education, as stated in Press Release No. 064/Sipres/A61lll/2020 regarding Prioritizing the Prevention of Covid-19, March 20, 2020. In Indonesia, up to two semesters, the pandemic has not been completely resolved, even data shows that it is often increasing. Learning for two semesters is still carried online. Reacting to the policy of the Ministry of Education and Culture, the higher education institution immediately made adjustments to the learning model applied, including the college where this research was developed. In this college, all learning in first semester of the pandemic is carried out online (Suryaman, Kusnan, \& Mubarok, 
The Readiness of Lecturers in Online Learning During the Covid-19 Pandemic at the Faculty of Information Technology and the Faculty of Economics and Business

2020), (Saputro, Saerozi, \& Ardhiansyah, 2020), (Arnove, 2020) although without adequate preparation.

It is said without adequate preparation because according to (Rasmitadila, et al., 2020) the success of online learning is influenced by the readiness of supporting technology that is integrated with the curriculum, support and collaboration from involved peers, including the government, schools, teachers, parents and the surrounding environment.

Meanwhile (Stacey \& Gerbic, 2018) divide the success factors in more detail, namely (1) success factors of educational institutions in the form of the readiness of network infrastructure, training for educators, motivation, space for educators to prepare material, (2) success factors for educators in the form of understanding the importance and usefulness of online learning, continuous mentoring, the consequences that can occur during learning online (3) the success factors of learners, in the form of the readiness of learners' hardwares, learners' expectations of online learning, the way of communicate that is not much different from face-to-face learning. The readiness that was already available before the pandemic was only in infrastructure, in the form of adequate campus bandwidth, while other readiness is not yet been planned, such as a curriculum designed to carry out online learning, at least through blended learning, readiness of learners' hardware and material made by lecturers to fulfill the self-instruction material so that lecturers do not only shift from physical to virtual, offline to online learning.

Even in circumstances without adequate preparation, online learning must be conducted. Applications that are mostly used during online learning are WhatsApp Group, Google Meet, and the campus' Learning Management System (LMS). Teaching and learning process (TLP) is carried out almost like meetings before the pandemic, namely direct interaction between lecturers and learners. If there are teaching materials, lecturers upload teaching materials on the campus' LMS, which is called Brillian, for learners to download. Meetings between lecturers and learners are conducted through Google Meet, where lecturers explain materials that have been uploaded to Brillian throughout the course time provided. Assessment in the form of assignments, quizzes is also carried out online, lecturers provide questions through the assignment menu on Brillian, then learners download and work on asynchronously with lecturers, and upload them back at Brilian. Likewise, midterm and final semester exams are conducted through Brilian, a campus e-learning based on Google Apps for Education (GAFE). A brief overview of learning during the first semester of Covid-19 pandemic on the campus where the research conducted can be seen at Figure 1. 
The Readiness of Lecturers in Online Learning During the Covid-19 Pandemic at the Faculty of Information Technology and the Faculty of Economics and Business

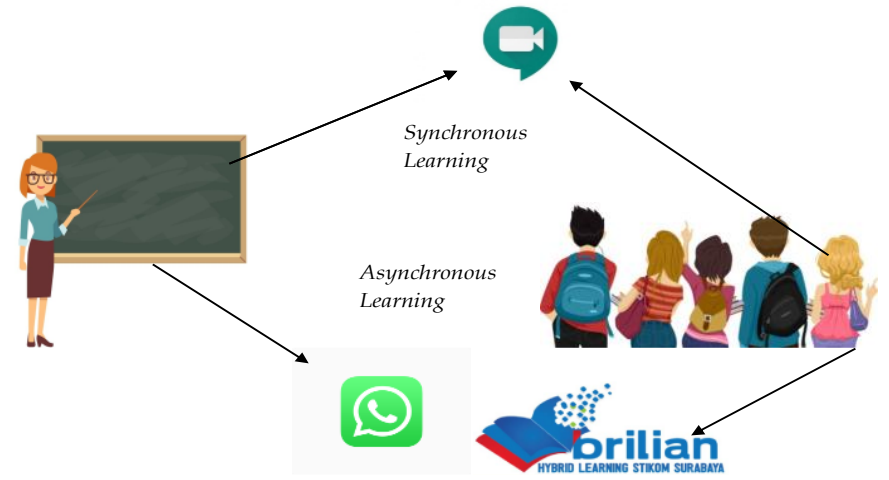

Figure 1. Teaching and learning process during pandemic Covid-19.

Online learning is a term that has become frequently used since the pandemic, although in fact the term has a meaning not different from e-learning (Sujarwo, Sukmawati, Akhiruddin, Ridwan, \& Siradjuddin, 2020), (Indrawan \& Cipta Nugraha, 2020), (Rasmitadila, et al., 2020). Online learning has many varieties and types, it was developed since 2002 (Chaeruman, Wibawa, \& Syahrial, 2020), and is form of technological development in aspects of human life, especially in education. There are various definitions of online learning, one of them is the results of innovative developments in information technology in the world of education which have brought about real changes in learning models (Fandino, Munoz, \& Velandia, 2019), (Haider \& Al-Salman, 2020). Online learning is learning that includes various technologies using the internet, such as web, email, chat, YouTube, and text around the world, audio and video conferences sent via computer networks to provide teaching materials (Dhull \& MS, 2017). Meanwhile, online learning is defined as a learning experience in a synchronous or asynchronous environment but uses several different devices, and is always followed by internet access, so that even though it is not at the same time, but between learnerseducators as well as among learners themselves (Singh \& Thurman, 2019). they can always interact one to another. Basically, online learning is a way of teaching and learning in which educators and learners meet virtually, and physically, either through synchronous (direct) or asynchronous (indirect) modes. Synchronous Learning is a learning model that is similar to conventional learning, but uses virtual classes, so there is no physical encounter between educators and learners (Rasmitadila, et al., 2020), while Asynchronous Learning is a form of indirect learning, not at the same time. and prioritizes independent learning. Regarding these two modes, (Shahabadi \& Uplane, 2015) state that the two modes in online learning can be used interchangeably and complement each other, to provide variations in delivering more interesting learning. Both synchronous and asynchronous modes have their own respective advantages, so that if used with the right portion, it will certainly produce an interesting learning for learners. Synchronous mode is not appropriate if it is carried out continuously, because the concentration of learners in following virtual learning is certainly not as long as when following direct face-to-face learning, in addition to the internet connection in learners' areas which is often inadequate (Bakalar, 2018). 
The Readiness of Lecturers in Online Learning During the Covid-19 Pandemic at the Faculty of Information Technology and the Faculty of Economics and Business

Online learning needs to be interspersed with asynchronous mode, so that learners can prepare first or after synchronizing with materials given. When in asynchronous mode, teachers can provide various kinds of material, ranging from videos that are made by themselves, or taken from other sources such as YouTube, to teaching materials other than power points, but in the form of textbooks, student activity sheets and many other unlimited materials. can be served while in this mode. Asynchronous mode is also expected to be able to train learners' independent learning abilities (Song \& J. Bonk, 2016). From these two modes, lecturers' role is very important, because the instructor as a learning architect must be able to maximize it, so as to produce interesting, fun and understandable teaching and learning process. (Hariadi, Sunarto, Sudarmaningtyas, \& Jatmiko, 2019) state that the role of educators to make more perfect online learning is very vital, because only educators have mastered the problems in their class. from materials to be given, to the special nature of learners in their classes. In addition to the teaching role, current technology assistance enables teachers to create teaching materials in both synchronous and asynchronous modes according to the wishes of today's learners (Sunarto, Hariadi, Sagirani, Amelia, \& Lemantara, 2020).

\section{Research Problem}

The research problem here is how being the readiness of the lecturers during online learning using synchronous and asynchronous modes at the Faculty of Technology and Information and the Faculty of Economics and Business at a University in Surabaya?

\section{Research Focus}

The focus of this research is to determine the readiness of the lecturers in implementing online learning especially in implementing the synchronous mode and the use of campus e-learning as an asynchronous mode at the Faculty of Information Technology and the Faculty of Business Economics, as well as the strengths and weaknesses of online learning that have been carried out by the lecturers.

\section{RESEARCH METHOD}

\section{Sample and Population}

Data collection was carried out through lecturer activity logs in carrying out online learning during the even semester of the 2019/2020 academic year. From the first week of lecturing to the last week of lecturing, lecturer logs for synchronous and asynchronous modes are recorded in the network section. Records from synchronous mode in the form of logs on google meet conducted by the lecturers, namely data on the time and duration of virtual contact with google meet. Meanwhile, the record from asynchronous mode was logs of how many course materials and how many assessments (in the form of assignments, quizzes, or exams) were uploaded on the campus e-learning,

Teaching activity logs recorded from the network section on campus are logs that can describe lecturers' activities while carrying out online learning, and are important logs for activity evaluation, although they cannot fully describe events during learning process (Pedro \& Kumar, 2020). The logs are then compared with the standards for the 
The Readiness of Lecturers in Online Learning During the Covid-19 Pandemic at the Faculty of Information Technology and the Faculty of Economics and Business

implementation of online learning, which are compiled based on several sources (Frydenberg, 2012), (iNACOL, 2011). The research method used is descriptive research, involving 126 lecturers who taught 350 classes at the two faculties during the first semester of the Covid-19 pandemic. A test can have high validity if the test performs its measuring function, or provides precise and accurate measurement results by the test's purpose. At the same time, reliability is the consistency of the size. Because the test tool for obtaining data comes from a Google Engine, it can be believed that this test tool has high validity and reliability.

\section{Instrument and Procedure}

After the logs ere obtained globally of 350 classes, they are grouped based on courses in a study program or other words, the logs were grouped based on the class of courses of a lecturer. This was done because the grouping is more focused on the study program which increases to the Faculty. There are 9 study programs on this campus, which consists of 2 faculties. After the logs were obtained and grouped, then the mean was looked for in each study program, then the mean in each faculty. This was performed for Gmeet activities as synchronous mode and course material, reference and assessment activities as asynchronous modes can be seen in Figure 2.

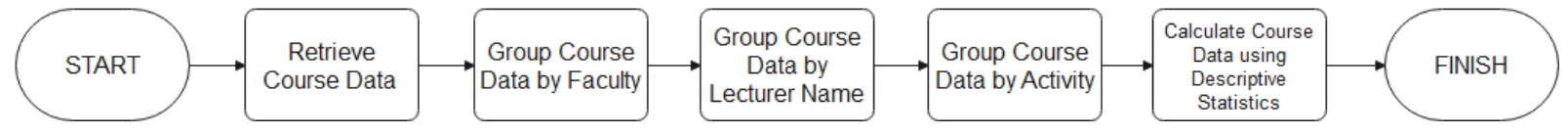

Figure 2. The flowchart of procedure research.

The research instrument is in the form of records/logs obtained from the network section can be used as quantitative data, then processed to become information (Campos, et al., 2019). Logs cannot be deleted or modified, so their accuracy can be guaranteed, because they are records from a machine.

\section{RESULT AND DISCUSSION \\ Data and Analyzes Data}

Details of data acquisition for each faculty, which were obtained from details in each study program, for synchronous and asynchronous modes, with a comparison of 14 meetings in one semester, can be seen in Table 1 to Table 11.

Table 1. Teaching activities logs in the undergraduate study program of information systems, faculty of information technology.

\begin{tabular}{|c|c|c|c|c|c|}
\hline $\begin{array}{c}\text { Number of } \\
\text { Lecturer }\end{array}$ & $\begin{array}{c}\text { Number of } \\
\text { Class }\end{array}$ & Mode & Activity & $\begin{array}{c}\begin{array}{c}\text { Number of } \\
\text { Note }\end{array} \\
\end{array}$ & Mean \\
\hline \multirow{4}{*}{44} & \multirow{4}{*}{97} & Synchronous & Gmeet & 985 & 10.15 \\
\hline & & \multirow{3}{*}{ Asynchronous } & Course Material & 1498 & 15.44 \\
\hline & & & Reference & 171 & 1,76 \\
\hline & & & Assessment & 335 & 3.45 \\
\hline
\end{tabular}


The Readiness of Lecturers in Online Learning During the Covid-19 Pandemic at the Faculty of Information Technology and the Faculty of Economics and Business

Table 2. Teaching activities logs in the diploma study program of information systems, faculty of information technology.

\begin{tabular}{|c|c|c|c|c|c|}
\hline $\begin{array}{c}\text { Number of } \\
\text { Lecturer }\end{array}$ & $\begin{array}{c}\text { Number of } \\
\text { Class }\end{array}$ & Mode & Activity & $\begin{array}{c}\text { Number of } \\
\text { Note }\end{array}$ & Mean \\
\hline \multirow{4}{*}{12} & \multirow{4}{*}{24} & Synchronous & Gmeet & 305 & 12.70 \\
\hline & & \multirow{3}{*}{ Asynchronous } & Course Material & 356 & 14.83 \\
\hline & & & Reference & 92 & 3.83 \\
\hline & & & Assessment & 95 & 3.95 \\
\hline
\end{tabular}

Table 3. Teaching activities logs in the undergraduate study program of computer systems, faculty of information technology.

\begin{tabular}{|c|c|c|c|c|c|}
\hline $\begin{array}{l}\text { Number of } \\
\text { Lecturer }\end{array}$ & $\begin{array}{c}\text { Number of } \\
\text { Class }\end{array}$ & Mode & Activity & $\begin{array}{c}\text { Number of } \\
\text { Note }\end{array}$ & Mean \\
\hline \multirow{4}{*}{16} & \multirow{4}{*}{36} & Synchronous & Gmeet & 397 & 11.02 \\
\hline & & \multirow{3}{*}{ Asynchronous } & Course Material & 343 & 9.52 \\
\hline & & & Reference & 10 & 0.27 \\
\hline & & & Assessment & 111 & 3.08 \\
\hline
\end{tabular}

Table 4. Teaching activities logs in the undergraduate study program of visual communication design, faculty of information technology.

\begin{tabular}{|c|c|c|c|c|c|}
\hline $\begin{array}{c}\begin{array}{c}\text { Number of } \\
\text { Lecturer }\end{array} \\
\end{array}$ & $\begin{array}{c}\text { Number of } \\
\text { Class }\end{array}$ & Mode & Activity & $\begin{array}{c}\text { Number of } \\
\text { Note }\end{array}$ & Mean \\
\hline \multirow{4}{*}{22} & \multirow{4}{*}{58} & Synchronous & Gmeet & 461 & 7.94 \\
\hline & & \multirow{3}{*}{ Asynchronous } & Course Material & 429 & 7.39 \\
\hline & & & Reference & 42 & 0.72 \\
\hline & & & Assessment & 268 & 4.62 \\
\hline
\end{tabular}

Table 5. Teaching activities logs in the undergraduate study program of visual communication design, faculty of information technology.

\begin{tabular}{ccclcc}
\hline $\begin{array}{c}\text { Number of } \\
\text { Lecturer }\end{array}$ & $\begin{array}{c}\text { Number of } \\
\text { Class }\end{array}$ & \multicolumn{1}{c}{ Mode } & \multicolumn{1}{c}{ Activity } & $\begin{array}{c}\text { Number of } \\
\text { Note }\end{array}$ & Mean \\
\hline \multirow{3}{*}{13} & \multirow{2}{*}{25} & Synchronous & Gmeet & 253 & 10.12 \\
\cline { 3 - 6 } & \multirow{2}{*}{ Asynchronous } & Course Material & 294 & 11,76 \\
\cline { 4 - 6 } & & & Reference & 6 & 0.24 \\
\cline { 4 - 6 } & & & Assessment & 79 & 3.16 \\
\hline
\end{tabular}

Table 6. Teaching activities logs in the undergraduate study program of film and television production, faculty of information technology.

\begin{tabular}{ccclcc}
\hline $\begin{array}{c}\text { Number of } \\
\text { Lecturer }\end{array}$ & $\begin{array}{c}\text { Number of } \\
\text { Class }\end{array}$ & \multicolumn{1}{c}{ Mode } & \multicolumn{1}{c}{ Activity } & $\begin{array}{c}\text { Number of } \\
\text { Note }\end{array}$ & Mean \\
\hline \multirow{3}{*}{18} & \multirow{2}{*}{35} & Synchronous & Gmeet & 362 & 10.34 \\
\cline { 3 - 6 } & \multirow{2}{*}{ Asynchronous } & Course Material & 246 & 7.02 \\
\cline { 4 - 6 } & & & Reference & 5 & 0.14 \\
\cline { 4 - 6 } & & & Assessment & 44 & 1.15 \\
\hline
\end{tabular}


The Readiness of Lecturers in Online Learning During the Covid-19 Pandemic at the Faculty of Information Technology and the Faculty of Economics and Business

Table 7. Teaching activities logs in the undergraduate study program of management, faculty of economics and business.

\begin{tabular}{|c|c|c|c|c|c|}
\hline $\begin{array}{c}\text { Number of } \\
\text { Lecturer }\end{array}$ & $\begin{array}{c}\text { Number of } \\
\text { Class }\end{array}$ & Mode & Activity & $\begin{array}{c}\text { Number of } \\
\text { Note }\end{array}$ & Mean \\
\hline \multirow{4}{*}{14} & \multirow{4}{*}{29} & Synchronous & Gmeet & 270 & 9.31 \\
\hline & & \multirow{3}{*}{ Asynchronous } & Course Material & 193 & 6.65 \\
\hline & & & Reference & 9 & 0.31 \\
\hline & & & Assessment & 96 & 3.31 \\
\hline
\end{tabular}

Table 8. Teaching activities logs in the undergraduate study program of accounting, faculty of economics and business.

\begin{tabular}{|c|c|c|c|c|c|}
\hline $\begin{array}{l}\text { Number of } \\
\text { Lecturer }\end{array}$ & $\begin{array}{c}\text { Number of } \\
\text { Class }\end{array}$ & Mode & Activity & $\begin{array}{c}\text { Number of } \\
\text { Note }\end{array}$ & Mean \\
\hline \multirow{4}{*}{19} & \multirow{4}{*}{27} & Synchronous & Gmeet & 277 & 10.25 \\
\hline & & \multirow{3}{*}{ Asynchronous } & Course Material & 196 & 7.25 \\
\hline & & & Reference & 24 & 0.89 \\
\hline & & & Assessment & 86 & 3.18 \\
\hline
\end{tabular}

Table 9. Teaching activities logs in the diploma program of office administration, faculty of economics and business.

\begin{tabular}{|c|c|c|c|c|c|}
\hline $\begin{array}{l}\text { Number of } \\
\text { Lecturer }\end{array}$ & $\begin{array}{c}\text { Number of } \\
\text { Class }\end{array}$ & Mode & Activity & $\begin{array}{c}\text { Number of } \\
\text { Note }\end{array}$ & Mean \\
\hline \multirow{4}{*}{12} & \multirow{4}{*}{19} & Synchronous & Gmeet & 173 & 9.11 \\
\hline & & \multirow{3}{*}{ Asynchronous } & Course Material & 136 & 7.15 \\
\hline & & & Reference & 11 & 0.58 \\
\hline & & & Assessment & 94 & 4.94 \\
\hline
\end{tabular}

Table 10. Average teaching activity notes of faculty of information technology (Table 1 - Table 6).

\begin{tabular}{llc}
\hline \multicolumn{1}{c}{ Mode } & \multicolumn{1}{c}{ Activity } & Mean \\
\hline Synchronous & Gmeet & 10.39 \\
\hline \multirow{2}{*}{ Asynchronous } & Course Material & 13.19 \\
\cline { 2 - 3 } & Reference & 1.16 \\
\cline { 2 - 3 } & Assessment & 3.88 \\
\hline
\end{tabular}

Table 11. Average teaching activity notes of faculty of economics and business (Table 7 Table 9).

\begin{tabular}{lll}
\hline \multicolumn{1}{c}{ Mode } & \multicolumn{1}{c}{ Activity } & Mean \\
\hline Synchronous & Gmeet & 9.56 \\
\hline \multirow{2}{*}{ Asynchronous } & Course Material & 7.02 \\
\cline { 2 - 3 } & Reference & 0.59 \\
\cline { 2 - 3 } & Assessment & 3.81 \\
\hline
\end{tabular}


The Readiness of Lecturers in Online Learning During the Covid-19 Pandemic at the Faculty of Information Technology and the Faculty of Economics and Business

Based on Tables 1 to 11, data shows that the use of synchronous learning with Google Meet is used about 10 times on average at the Faculty of Information Technology, and about 9 times at the Faculty of Economics and Business, out of 14 scheduled meetings in one semester, or around $64 \%$ in the Faculty of Economics and Business, and $72 \%$ in the Faculty of Technology and Information. In general, the use of synchronous learning mode with an average of $68 \%$ is considered adequate, because this mode is indeed the closest to traditional learning that has been used so far, so that learners are accustomed and comfortable, but on the one hand, if the use of this mode is too much, it will cause boredom in learners. (Perveen, 2016) found that the synchronous learning mode is very effective to use as scaffolding from educators to learners, because learners can directly ask the problem they are facing, as long as it is used in the right portion and not continuously. Meanwhile (Martin \& A. Parker, 2014) found that the synchronous mode can be used to help motivate learners, as long as educators are familiar with the conditions of learners' environment, and is used with the right amount of port in and time. However, educators must also pay attention to several things that must be prepared in using synchronous mode, as stated by (Hyder, Kwinn, Miazga, \& Murray, 2017) in a book entitled The eLearning Guild's Handbook on Synchronous e-Learning, namely: (1) understanding the philosophy of synchronous mode (readiness of educators as content creators, readiness of e-learning application features, readiness of producers to handle the entire process), (2) understanding the design of virtual classrooms (how long this mode is used so that it is not boring, how to maximize interaction, means of making virtual classrooms), (3) preparing to make synchronous modes (introduction to learners who will be faced in virtual classes, whether teaching assistants are needed or not, making appropriate instructional designs, preparing supporting hardware), (4) attention during learning in synchronous mode, (5) evaluation of the results. In the first semester of this pandemic period, with sudden preparation, the data on lecturers' teaching logs showed that in general, very little understanding on the philosophy of synchronous mode was prepared, except for the readiness of the features of the e-learning application, which indeed has been held for the last 5 years. There is no specific training for lecturers on understanding the existing modes, or as a content creator.

Likewise, in item 2, namely in understanding the design of virtual classrooms, lecturers are not equipped with how to run synchronous mode, the time used, or in investigating the hardware and software capabilities of each learner. Preparation for synchronous mode in item 3 was only done in the hardware preparation of lecturers. Item 4 also cannot be prepared properly, while evaluation has been carried out by conducting questionnaires to learners to find out their level of satisfaction with online learning. As for the use of asynchronous mode which is divided into (1) course materials (material uploading as teaching material as companion to materials that can be studied before or after synchronous mode), (2) references (supporting material, in the form of eBooks, articles and others can be used for 1 semester, and not only at certain meetings), (3) assessment (can be in the form of assignments, quizzes, exams). Course materials, references and assessments, are all contained in the campus e-learning which is called 
The Readiness of Lecturers in Online Learning During the Covid-19 Pandemic at the Faculty of Information Technology and the Faculty of Economics and Business

Brillian, and qualifies as materials for independent study, after learners do synchronous mode (Murphy, Rodríguez-Manzanares, \& Barbour, 2011). On the course material menu, the faculty of technology and informatics has 13 files on average in one semester, which means that in one meeting, there is one file uploaded, this is in accordance with the definition of asynchronous, namely that teaching materials are provided separately and can serve as pioneer, companion or enrichment of educators' explanations (Littlefield, 2018). While at the Faculty of Economics and Business, since there are only 7 files on average in one semester, it must be increased. While the reference menu has not been optimized yet. Every effort should be made to make online learning in times of a pandemic become a more mindful, authentic, and humanly paced approach, disruption from the present model is needed (Hughes, 2020).

\section{CONCLUSIONS}

The impact of the Covid-19 pandemic in the world of education is very pronounced, especially in the changes in learning system, from offline to online, traditional to virtual. Online learning, which is actually nothing new and has been aspired to since the last decade, is now being materialized because of the acceleration caused by Covid-19, although it is not yet perfect because of unwell-prepared planning. Both modes of online learning have been implemented, but the readiness of lecturers for synchronous implementation is merely on the use of applications, without preparing the understanding on philosophy and other conditions in that mode, so it is likely to cause boredom in learners. Meanwhile, the role of lecturers in implementing asynchronous is by creating teaching materials that serve as pioneer, companion and enrichment at each meeting, but it is still minimally used as reference. In the second semester of the Covid19 pandemic, there are still a number of things that are improved to make online learning more well-prepared, including the preparation of lecturers as content creators, understanding the conditions of learners during online learning, philosophy of online learning, and improvements to the e-learning application to make it easier to use (Daniel, 2020). This research has implications for the awareness that online learning which is carried out suddenly, without proper preparation and understanding the philosophy well, is the same as shift from traditional to virtual class. This kind of characteristic has the potential to reduce the motivation of learners in participating in teaching learning process (Kauffman, 2015), especially without being preceded by observations of the infrastructure learners have when participating in online learning (Huber \& Helm, 2020). The limitation of this study is that there has not been an evaluation of the results of online learning during the first semester of the Covid-19 pandemic. Recommendations for further research are evaluating the results during online learning, and distributing questionnaires to learners so that it can be found out the perceptions from learners' point of views. 
The Readiness of Lecturers in Online Learning During the Covid-19 Pandemic at the Faculty of Information Technology and the Faculty of Economics and Business

\section{REFERENCES}

Arnove, R. F. (2020). Imagining what education can be post-Covid-19. Prospects, 49, 4346.

Bakalar, B. (2018). Book Review : Justice on both sides: Transforming education through restorative justice. American Journal of Qualitative Research, 2(2), 145-149.

Campos, A., Fantini, W. d., Ciriaco, M. A., Santos, J. d., Moreira, F., \& Gomes, A. S. (2019). Health Student using google classroom: Satisfaction analysis. In A. Campos, Learning Technology for Education Challenges (pp. 58-66). Switzerland: Springer, Cham.

Chaeruman, U. A., Wibawa, B., \& Syahrial, Z. (2020). Development of an instructional system design model as a guideline for lecturers in creating a course using blended learning approach. International Journal of Interactive Mobile Technologies (iJIM), 14(4), $164-182$.

Daniel, S. J. (2020). Education and the Covid-19 pandemic. Prospects, 49, 91-96.

Dhull, I., \& MS, S. (2017). Online learning. International Education \& Research Journal (IERJ), 3(8), 32-35.

Fandino, F. G., Munoz, L. D., \& Velandia, A. J. (2019). Motivation and E-Learning english as a foreign language: A qualitative study. Heliyon, 5(9), 1-7.

Frydenberg, J. (2012). Quality standards in e-learning: a matrix of analysis. International Review of Research in Open and Distance Learning, 9(2), 1-15.

Haider, A. S., \& Al-Salman, S. (2020). Dataset of Jordanian university students' psychological health impacted by using e-learning tools during COVID-19. Data in Brief, 32, 1-8.

Hariadi, B., Sunarto, M. D., Sudarmaningtyas, P., \& Jatmiko, B. (2019). Hybrid Learning by using brilian applications as one of the learning alternatives to improve learning outcomes in college. International Journal of Emerging Technologies in Learning (iJET), 14(10), 34-45.

Huber, S. G., \& Helm, C. (2020). COVID-19 and schooling: evaluation, assessment and accountability in times of crises - reacting quickly to explore key issues for policy, practice and research with the school barometer. Educational Assessment, Evaluation and Accountability, 32, 237-270.

Hughes, C. (2020). COVID-19 and the opportunity to design a more mindful approach to learning. Prospects, 49, 69-72.

Hyder, K., Kwinn, A., Miazga, R., \& Murray, M. (2017). The eLearning guild's handbook on Synchronous e-Learning. Santa Rosa, CA: The eLearning Guild.

iNACOL. (2011). National standards for quality online teaching. Vienna: International Association 16 For K-12 Online Learning.

Indrawan, I. P., \& Cipta, N. P. G. (2020). Rancangan dan implementasi sistem e-learning berbasis web. Jurnal Pedagogi dan Pembelajaran, 3(3), 367-374.

Kauffman, H. (2015). A review of predictive factors of student success in and satisfaction with online learning. Research in Learning Technology, 23, 1-13.

Littlefield, J. (2018, January 14). ThoughtCo. Retrieved from The Difference Between Synchronous and Asynchronous Distance Learning 
The Readiness of Lecturers in Online Learning During the Covid-19 Pandemic at the Faculty of Information Technology and the Faculty of Economics and Business

https://www.thoughtco.com/synchronous-distance-learning-asynchronousdistance-learning-1097959

Martin, F., \& A. Parker, M. (2014). Use of synchronous virtual classrooms: why, who, and how? MERLOT Journal of Online Learning and Teaching, 10(2), 192-210.

Murphy, E., Rodríguez-Manzanares, M. A., \& Barbour, M. (2011). Asynchronous and synchronous online teaching: Perspectives of Canadian high school distance education teachers. British Journal of Educational Technology, 42(4), 583-591.

Pedro, N. S., \& Kumar, S. (2020). Institutional Support for online teaching in quality assurance frameworks. Online Learning, 24(3), 50-66.

Perveen, A. (2016). Synchronous and asynchronous e-language learning: A case study of virtual university of Pakistan. Open Praxis, 8(1), 21-39.

Rasmitadila, Aliyyah, R. R., Rachmadtullah, R., Samsudin, A., Syaodih, E., Nurtanto, M., \& Tambunan, A. R. (2020). The perception of primary school teachers of online learning during the covid-19 pandemic period : A case study in Indonesia. Journal of Ethnic and Cultural Studies, 7(2), 90-109.

Saputro, B., Saerozi, M., \& Ardhiansyah, F. (2020). Philosophical reflections : Critical analysis of learning strategies for science practicum during the covid-19 Pandemic. International Journal of Recent Educational Education, 1(2), 78-89.

Shahabadi, M. M., \& Uplane, M. (2015). Synchronous and asynchronous e-learning styles and academic performance of e-learners. Procedia - Social and Behavioral Sciences, 176, 129-138.

Singh, V., \& Thurman, A. (2019). How many ways can we define online learning? A systematic literature review of definitions of online learning (1988-2018). American Journal of Distance Education, 33(4), 289-306.

Song, D., \& J. Bonk, C. (2016). Motivational factors in self-directed informal learning from online learning resources. Cogent Education, 3, 1-11.

Stacey, E., \& Gerbic, P. (2018). Success factor for blended learning. Proceedings ascilite Melbourne 2008, (pp. 964-968). Melbourne.

Sujarwo, Sukmawati, Akhiruddin, Ridwan, \& Siradjuddin, S. (2020). An analysis of university students" perspective on online learning in the midst of Covid-19 pandemic. Jurnal Pendidikan dan Pengajaran, 53(2), 125-137.

Sunarto, M. D., Hariadi, B., Sagirani, T., Amelia, T., \& Lemantara, J. (2020). MoLearn, a web-and android-based learning application as an alternative for teaching-learning process in high schools. International Journal of Instruction, 13(1), 53-70.

Suryaman, H., Kusnan, \& Mubarok, H. (2020). Profile of online learning in building engineering education study program during the COVID-19 Pandemic. International Journal of Recent Educational Education, 1(2), 63-77. 
The Readiness of Lecturers in Online Learning During the Covid-19 Pandemic at the Faculty of Information Technology and the Faculty of Economics and Business

*Dr. M. J. Dewiyani Sunarto (Corresponding Author)

Department of Information System, Faculty Technology and Informatics

Universitas Dinamika

Jalan Raya Kedung Baruk 98, Surabaya

Email: dewiyani@dinamika.ac.id 